\title{
Isolation, Characterization, and Taxonomy of Aquaspirillum bengal sp.nov.
}

\author{
RANAJIT KUMAR, A. K. BANERJEE, J. H. BOWDRE, L. J. McELROY, and N. R. KRIEG \\ Department of Botany, Burdwan University, Burdwan, West Bengal, India; Department of Biology, \\ Beaver Campus, The Pennsylvania State University, Monaca, Pennsylvania 15061; and \\ Department of Biology, Virginia Polytechnic Institute and State University, \\ Blacksburg, Virginia 24061
}

\begin{abstract}
A large spirillum was isolated from a freshwater pond in West Bengal. Its deoxyribonucleic acid base composition ( $51 \mathrm{~mol} \%$ guanine + cytosine) and cell diameter $(0.9$ to $1.2 \mu \mathrm{m}$.) were similar to those of Aquaspirillum serpens and $A$. putridiconchylium. Although its characteristics corresponded more closely to those of the latter species than of any other, the spirillum is unique in having an unusually high temperature for optimal growth $(41 \mathrm{C})$, in forming water-soluble pigments from tyrosine and tryptophan, and in several other nutritional, biochemical, and serological characteristics. On the basis of these differences, the isolate was proposed as a new species, Aquaspirillum bengal. The type strain was deposited with the American Type Culture Collection under the number 27641.
\end{abstract}

Because of their helical shape, spirilla have attracted attention since the beginnings of the science of microbiology. Although spirilla are widely distributed in freshwater and marine environments, they are relatively difficult to isolate $(1,5,9,10)$, and the characterization of the genus Spirillum has not been extensive until recent years. A comprehensive characterization of spirilla has been provided by Terasaki $(6,7)$ and by Hylemon et al. (2). The latter authors proposed a division of the genus into three genera: Spirillum (containing obligately microaerophilic freshwater spirilla possessing a deoxyribonucleic acid [DNA] base composition of $38 \mathrm{~mol} \%$ guanine + cytosine $[\mathrm{G}+\mathrm{C}])$, Aquaspirillum (containing aerobic freshwater forms possessing a $\mathrm{G}+\mathrm{C}$ composition of 49 to $65 \mathrm{~mol} \%$ ), and Oceanospirillum (containing marine spirilla having a $\mathrm{G}+\mathrm{C}$ composition of 42 to $48 \mathrm{~mol} \%$ ).

While searching for freshwater spirilla in West Bengal, we discovered a large spirillum whose numbers varied with environmental temperature. The organism appeared to represent a new species of Aquaspirillum, and the present report deals with its isolation, characterization, and taxonomic status.

\section{MATERIALS AND METHODS}

Source of the organism. Out of 30 inland freshwater ponds scattered over the districts of Burdwan and Hooghly in West Bengal, water samples from one pond in Khanyan in the Hooghly district were found to contain large spirilla. The organisms were detectable in microscopic examination of wet mounts only during months when the temperature of the pond water was $30 \mathrm{C}$ or above. The population density was maximal during June and July when the water temperature was 34 to $36 \mathrm{C}$, and consequently enrichment techniques and isolation of the organism were performed at this time. Attempts to obtain enrichment cultures of the spirilla during the cooler months were largely unsuccessful.

Enrichment and isolation. Enrichment was accomplished by adding $10 \mathrm{ml}$ of the pond-water samples to $90 \mathrm{ml}$ of sterile $0.5 \%$ peptone (Oxoid) contained in $250-\mathrm{ml}$ Erlenmeyer flasks. The number of spirilla increased from their initial level of $10^{4}$ cells $/ \mathrm{ml}$ to a level 100 to 400 times greater within an incubation period of 24 to $72 \mathrm{~h}$ at room temperature $(30 \mathrm{C})$, but the enrichment was in no way selective. Incubation for longer periods resulted in a rapid decrease in the spirilla.

After enrichment, a further concentration of the spirilla was achieved by low-speed centrifugation $(1,000 \times g$ for $5 \mathrm{~min})$; the spirilla, being comparatively larger than the other bacteria present, were sedimented more rapidly. The supernatant was carefully decanted, and the sediment was suspended in $2 \mathrm{ml}$ of sterile tap water.

For isolation, two techniques were tried. A glass capillary method, which made use of the faster motility of spirilla compared with other bacteria present and which had been used sucessfully for isolation of Spirillum volutans by Rittenberg and Rittenberg (5) and by Wells and Krieg (9), proved ineffective. A dilution plating method, however, did prove successful. From a series of decimal dilutions of the concentrated spirilla, $0.1-\mathrm{ml}$ samples were spread 
on the surface of various solidified media. Colonies were obtained only on the following medium: Evans peptone, $5.0 \mathrm{~g}$; tomato extract (prepared by pressing pieces of fresh ripe tomatoes through cheesecloth and filtering the juice through paper), $40 \mathrm{ml}$; agar powder (Kobe, Japan), $20 \mathrm{~g}$; and pond water, 1,000 $\mathrm{ml}$. The pH was adjusted to 7.4 with $\mathrm{KOH}$, and the medium was sterilized at $121 \mathrm{C}\left(15 \mathrm{lb} / \mathrm{in}^{2}\right)$ for $15 \mathrm{~min}$. Dilution plates were incubated at $40 \mathrm{C}$ for $72 \mathrm{~h}$ and were then examined for the presence of colonies of spirilla with a low-power microscope. The selected colonies were transferred to slants of the tomato extract agar and purified by repeated dilution plating.

Characterization methods. Methods for the determination of cell dimensions, electron microscopy, biochemical and nutritional characteristics, and DNA base composition, as well as the test media employed, were as described by Hylemon et al. (2), with the exceptions and additional tests noted below. Intracellular granules were stained by the method of Neisser (4). All characterization tests were performed with cultures incubated at 40 to $41 \mathrm{C}$. The capacity of the organism to transfer electrons to methylene blue from various substrates was tested by the Thunberg technique (8). Minimal inhibitory concentrations of penicillin and streptomycin were determined by inoculating one loopful from a 24 -h-old culture to $1.0 \%$ peptone broth ( $\mathrm{pH} 6.8$ ) containing graded concentrations of either streptomycin sulfate or the potassium salt of benzyl penicillin. The growth response was estimated visually after $24 \mathrm{~h}$ of incubation at $40 \mathrm{C}$, and the lowest concentration of antibiotic that completely inhibited growth was determined. Utilization of compounds as sole carbon or sole nitrogen sources was tested as described by Hylemon et al. (2) with the following modifications: (i) the inoculum consisted of $0.05 \mathrm{ml}$ of a suspension prepared by culturing cells for $24 \mathrm{~h}$ in $10 \mathrm{ml}$ of peptone-succinate-salts broth (2) contained in a 20 - by $125-\mathrm{mm}$ tube, washing the cells once in sterile saline $(0.85 \% \mathrm{NaCl})$, and suspending the cells in saline to their original concentration. The inoculum contained an average count of $3 \times 10^{5}$ cells. (ii) Growth responses were measured with an EEL colorimeter (Evans Electroselenium Ltd., Halstead, Essex, England) using a green filter $(540 \mathrm{~nm})$ and $16-\mathrm{mm}$ cuvettes. Hylemon et al. (2) defined a positive growth response as the production of at least 10 Klett units of turbidity for the second serial transfer at $72-\mathrm{h}$ incubation, using a blue filter $(420 \mathrm{~nm})$ and $16-\mathrm{mm}$ cuvettes; this turbidity corresponded to a measurement of 0.03 with the EEL colorimeter, and a positive growth response was based on this value rather than on Klett units.

The degree of serological cross-reaction, with respect to thermolabile antigens, between the Bengal isolate and Aquaspirillum putridiconchylium ATCC 15279 was determined by methods previously described by McElroy and Krieg (3).

\section{RESULTS}

The morphological features of the organism and its colony characteristics are as follows: cell diameter, 0.9 to $1.2 \mu \mathrm{m}$; cell length, 5.2 to 22.0 $\mu \mathrm{m}$; wavelength, 4.6 to $8.1 \mu \mathrm{m}$; diameter of helix, 1.7 to $2.3 \mu \mathrm{m}$; swimming speed (measured for individual cells by use of a calibrated ocular micrometer and a stopwatch), 40 to 52 $\mu \mathrm{m} / \mathrm{s}$; colony diameter, 3 to $4 \mathrm{~mm}$. Intracellular granules were present. Flagellation was in bipolar tufts. Coccoid bodies in older cultures were not predominant. The colony color and density were light brown and translucent, respectively. Colony contour was a raised center with thinner flat periphery; colony margin was undulate to erose. An electron micrograph demonstrating the bipolar tufts of flagella is presented in Fig. 1.

An examination of wet mounts from peptone-succinate-salts broth cultures indicated that after approximately $5 \mathrm{~min}$ the organisms migrated toward the margin of the coverslip and formed a zone of concentration at a short distance from the margin in a manner similar to that previously reported for S. volutans (9). Such behavior suggested that the organisms might prefer microaerophilic conditions for growth. The organism did not possess the usual oxygen relations expected for aerobic bacteria in that mechanical shaking of cultures failed to increase the rate of growth. It is clear, however, that the organism is not an obligate microaerophile like $S$. volutans because it does grow well in an air atmosphere.

The spirillum exhibited no growth at 10 or 45 C. A maximal growth response occurred at $41 \mathrm{C}$ (Table 1). Slight growth occurred at $15 \mathrm{C}$ and moderate growth occurred from 20 to 37 $\mathrm{C}$, increasing with temperature. When the effect of $\mathrm{pH}$ of growth responses was tested in phosphate-buffered broth, the organisms tolerated a pH range from 6.0 to 8.4 , the optimum being 7.2 .

The biochemical characteristics, DNA base composition, and antibiotic sensitivities of the organism are summarized in Table 2 . The Thunberg methylene blue reduction technique indicated that acetate, lactate, glutamate, succinate, and malate, but not glucose, could serve as oxidizable substrates (Table 3).

Among 37 compounds offered as sole carbon sources [with $\left(\mathrm{NH}_{4}\right)_{2} \mathrm{SO}_{4}$ being supplied as a nitrogen source], the organism was able to utilize six out of eight organic acids and six out of 17 amino acids (Table 4). The best growth responses were obtained with alanine, pyruvate, and lactate. Sugars, sugar alcohols, and aliphatic alcohols were not utilized.

Compounds tested as sole nitrogen sources (with a combination of malate plus succinate being supplied as carbon sources) included 19 amino acids, urea, ammonium sulfate, and 


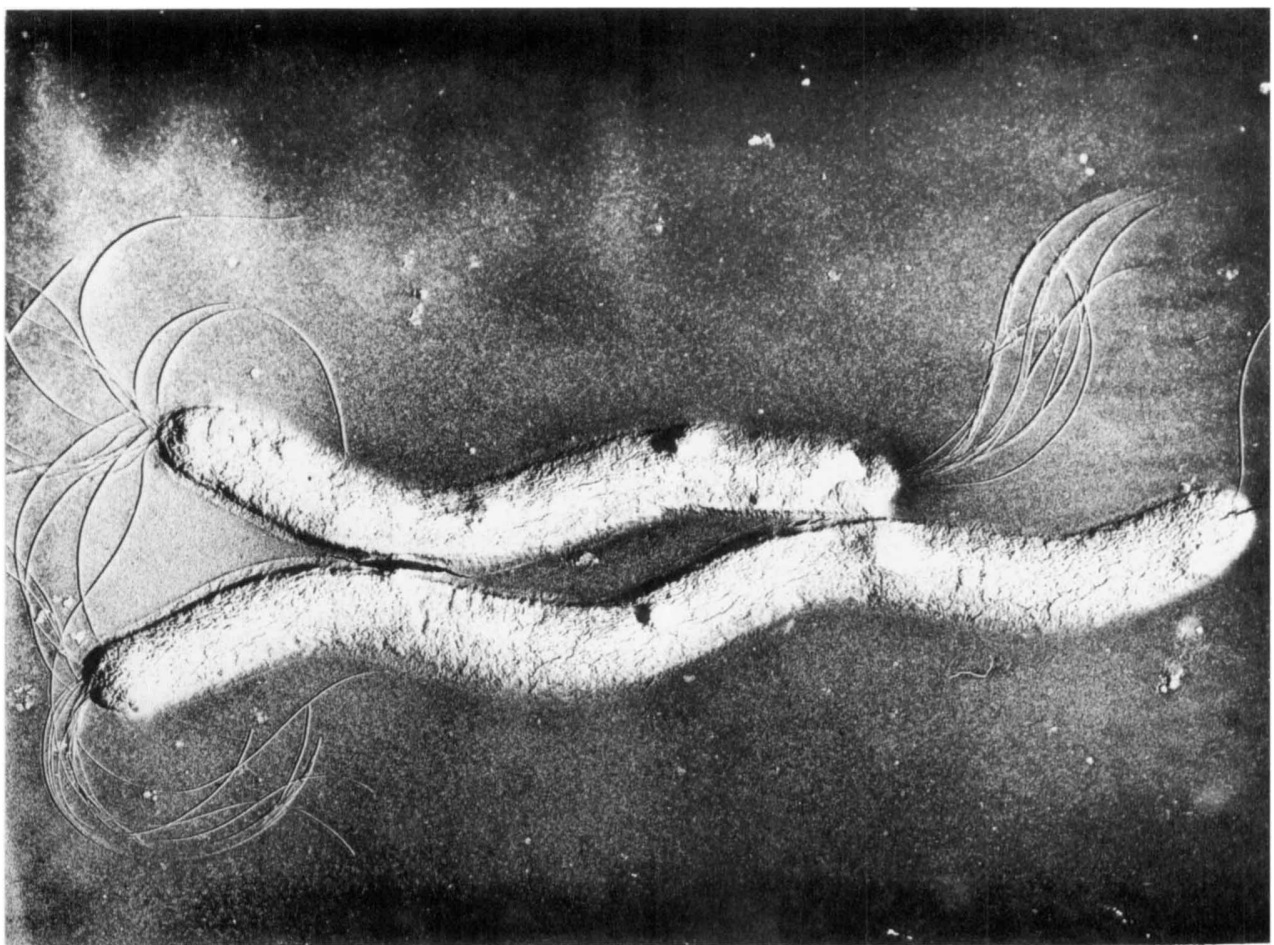

FIG. 1. Bipolar flagellar fascicles of $A$. bengal as seen by electron microscopy. 7,700x.

TABLE 1. Effect of temperature on growth of the Bengal aquaspirillum ${ }^{a}$

\begin{tabular}{c|c|c}
\hline $\begin{array}{c}\text { Temp } \\
\text { (C) }\end{array}$ & $\begin{array}{c}\text { Total cell count } \\
\text { ml at } 72 \mathrm{~h}^{b}\end{array}$ & $\begin{array}{c}\text { Turbidity } \\
\text { at } 72 \mathrm{~h} \mathrm{c}^{\mathrm{c}}\end{array}$ \\
\hline 10 & $<10^{4}$ & 0.00 \\
20 & $8.0 \times 10^{5}$ & 0.08 \\
30 & $1.0 \times 10^{6}$ & 0.20 \\
37 & $4.0 \times 10^{6}$ & 0.85 \\
38 & $4.3 \times 10^{6}$ & 0.85 \\
39 & $6.0 \times 10^{6}$ & 0.85 \\
40 & $8.0 \times 10^{6}$ & 1.00 \\
41 & $1.6 \times 10^{7}$ & 1.10 \\
42 & $3.0 \times 10^{6}$ & 0.75 \\
45 & $<10^{4}$ & 0.00 \\
\hline
\end{tabular}

${ }^{a}$ Inoculum per $10 \mathrm{ml}$ of peptone-succinate-salts broth $=1.6 \times 10^{6}$ cells cultured for $72 \mathrm{~h}$ at $36 \mathrm{C}$.

${ }^{b}$ As measured with a hemocy tometer.

${ }^{c}$ As estimated with an EEL colorimeter, using $16-\mathrm{mm}$ cuvettes and green $(540 \mathrm{~nm})$ filter.

potassium nitrate. As indicated in Table 5, all of these except five amino acids, urea, and nitrate were utilized. The best growth responses were obtained with glutamate, alanine, and asparagine.

Giesberger (Ph.D. thesis, Delft University, The Netherlands, 1936) reported that $\mathrm{Ca}^{2+}$ improved the growth responses of spirilla; however, Hylemon et al. (2) reported an inhibitory effect on growth. The growth of the Bengal spirillum was inhibited by 50 to $80 \%$ by addition of $0.05 \% \mathrm{CaCl}_{2}$ to the defined basal medium of Hylemon et al. (2) containing acetate, lactate, succinate, or glutamate as a carbon source.

Incorporation of varying amounts of $\mathrm{NaCl}$ into defined basal medium, containing a combination of succinate, pyruvate, and glutamate $(0.1 \%$ each) as the carbon source, indicated that the organism could tolerate $0.5 \% \mathrm{NaCl}$ but could not grow with $1.0 \% \mathrm{NaCl}$.

Homologous titers of anti-thermolabileantigen sera prepared against the Bengal isolate and against $A$. putridiconchylium ATCC 15279 were $1: 1,280$ and $1: 10,240$, respectively. When used at a dilution of $1: 20$, neither antiserum caused cross-agglutination with the heterologous strain.

\section{DISCUSSION}

Because the Bengal spirillum can grow aerobically, possesses a cell diameter of 0.9 to 1.2 $\mu \mathrm{m}$, has a DNA base composition of $51 \mathrm{~mol} \%$ $\mathrm{G}+\mathrm{C}$, is catalase and oxidase positive, fails to grow with $1 \% \mathrm{NaCl}$, cannot hydrolyze casein, 
TABLE 2. Summary of DNA base composition, biochemical characteristics, and antibiotic sensitivities of the Bengal aquaspirillum

\begin{tabular}{|c|c|}
\hline Test & Result \\
\hline 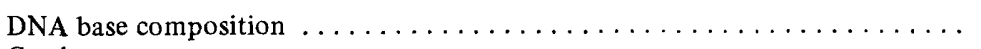 & $T_{m}{ }^{a}=90.1 \mathrm{C} ; \mathrm{mol} \% \mathrm{G}+\mathrm{C}=51$ \\
\hline 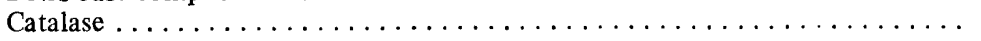 & $+a$ \\
\hline 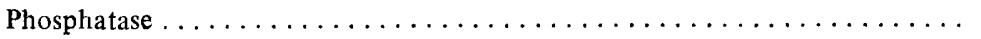 & + \\
\hline 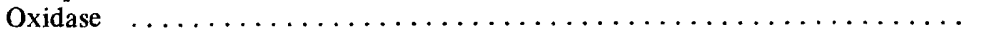 & + \\
\hline 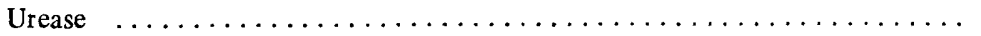 & $-{ }^{a}$ \\
\hline 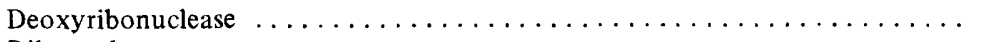 & $-(+$ at $37 \mathrm{C})$ \\
\hline 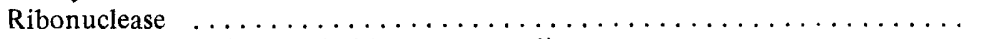 & - \\
\hline Hydrolysis of casein, starch, hippurate, esculin $\ldots \ldots \ldots \ldots \ldots \ldots$ & - \\
\hline 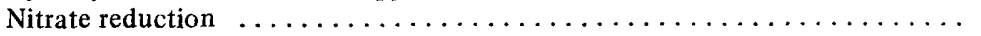 & - \\
\hline 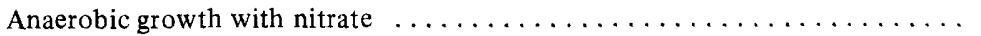 & - \\
\hline 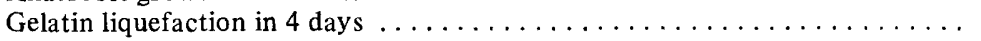 & - \\
\hline 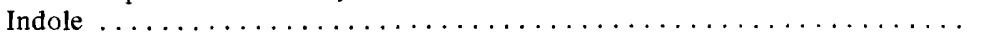 & - \\
\hline 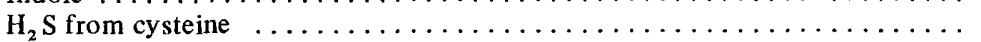 & + \\
\hline 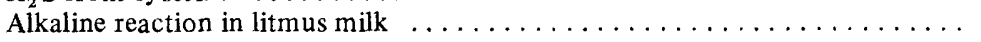 & - \\
\hline 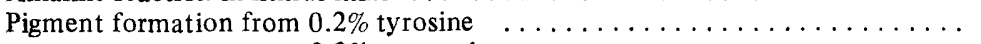 & Light brown, water soluble \\
\hline 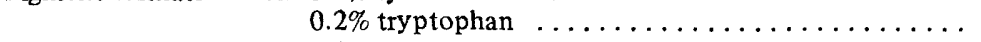 & Light brown, water soluble \\
\hline 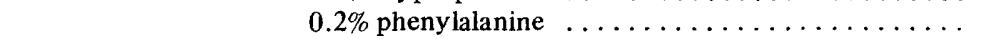 & - \\
\hline Acid reaction from carbohydrates $(31$ carbohydrates tested $) \ldots \ldots \ldots \ldots$ & - \\
\hline 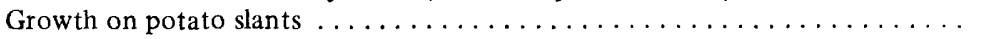 & - \\
\hline 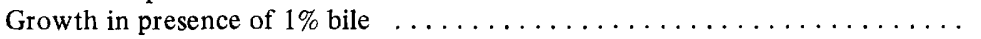 & + \\
\hline 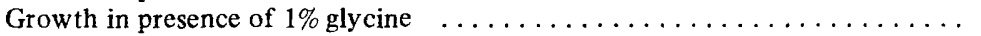 & - \\
\hline 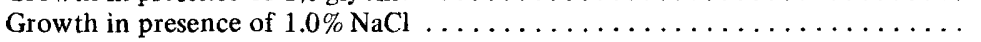 & - \\
\hline 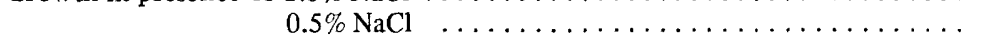 & + \\
\hline Growth on EMB or MacConkey agar $\ldots \ldots \ldots \ldots \ldots \ldots \ldots \ldots \ldots$ & - \\
\hline Growth on triple sugar iron agar or Seller agar $\ldots \ldots \ldots \ldots \ldots \ldots$ & + \\
\hline 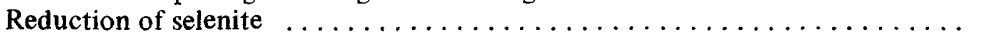 & - \\
\hline Formation of water-soluble fluorescent pigment $\ldots \ldots \ldots \ldots \ldots \ldots$ & - \\
\hline Presence of intracellular poly- $\beta$-hydroxybutyrate $\ldots \ldots \ldots \ldots \ldots \ldots$ & + \\
\hline Minimal inhibitory concentration of penicillin $\ldots \ldots \ldots \ldots \ldots \ldots \ldots \ldots \ldots \ldots \ldots$ & $50 \mathrm{IU} / \mathrm{ml}$ \\
\hline streptomycin $\ldots \ldots \ldots \ldots \ldots \ldots$ & $0.5 \mu \mathrm{g} / \mathrm{ml}$ \\
\hline
\end{tabular}

${ }^{a} T_{m}$, Melting temperature; +, positive; - , negative.

TABLE 3. Ability of the Bengal aquaspirillum to transfer electrons from various substrates to methylene blue $e^{a}$

\begin{tabular}{lc}
\hline & $\begin{array}{c}\text { Methylene blue } \\
\text { reduced in } 21 \\
\text { min at 37 C } \\
(\%)^{b}\end{array}$ \\
\hline Substrate & 82.0 \\
Lactate & 62.9 \\
Glutamate & 29.0 \\
Acetate & 22.2 \\
Succinate & 16.5 \\
Malate & 0.0 \\
Glucose & \\
\hline
\end{tabular}

${ }^{a}$ By the Thunberg technique.

${ }^{b}$ Corrected for endogenous reduction.

starch, hippurate, or esculin, is indole negative, and is of freshwater origin, it would appear to belong to the genus Aquaspirillum as defined by Hylemon et al. (2). The DNA base composition matches only two species within this genus: $A$. serpens $(\mathrm{G}+\mathrm{C}=50$ to $51 \mathrm{~mol} \%)$ and A. putridiconchylium $(\mathrm{G}+\mathrm{C}=52 \mathrm{~mol} \%)$ (2).
The cell diameter of the Bengal spirillum is also similar to those of these two species (0.6 to 1.1 $\mu \mathrm{m}$ for $A$. serpens and 0.9 to $1.1 \mu \mathrm{m}$ for $A$. putridiconchylium). The Bengal strain also resembles both of these species in several other ways: presence of poly- $\beta$-hydroxybutyrate; $a b-$ sence of coccoid bodies in older cultures; positive phosphatase reaction; $\mathrm{H}_{2} \mathrm{~S}$ from cysteine; ability to grow in the presence of $1 \%$ bile but not $1 \%$ glycine; inability to grow anaerobically with nitrate; failure to produce acid reactions from carbohydrates; failure to reduce selenite; and inability to use citrate, carbohydrates, aliphatic alcohols, tyrosine, arginine, lysine, leucine, isoleucine, valine, methionine, cysteine, or glycine as a sole carbon source. A further comparison of other characteristics for A. serpens and A. putridiconchylium (2) with those of the Bengal strain indicates that the latter resembles $A$. putridiconchylium to a greater extent than it does $A$. serpens; however, some differences between the Bengal strain and A. putridiconchylium do occur. These include the high optimal temperature for the Bengal 
TABLE 4. Sole carbon sources for the Bengal aquaspirillum with $\left(\mathrm{NH}_{4}\right)_{2} \mathrm{SO}_{4}$ as nitrogen source

\begin{tabular}{|c|c|}
\hline Compound & Growth response ${ }^{a}$ \\
\hline \multicolumn{2}{|l|}{$\overrightarrow{\text { Organic acids }}$} \\
\hline Formate & - \\
\hline Acetate & + \\
\hline Pyruvate & + \\
\hline Lactate & + \\
\hline Citrate & - \\
\hline Succinate & + \\
\hline Fumarate & + \\
\hline Malate & + \\
\hline \multicolumn{2}{|c|}{ Sugars and sugar alcohols } \\
\hline Arabinose & - \\
\hline Xylose & - \\
\hline Ribose & - \\
\hline Glucose & - \\
\hline Mannose & - \\
\hline Galactose & - \\
\hline Fructose & - \\
\hline Mannitol & - \\
\hline Glycerol & - \\
\hline \multicolumn{2}{|l|}{ Aliphatic alcohols } \\
\hline Ethanol & - \\
\hline$n$-Propanol & - \\
\hline n-Butanol & - \\
\hline \multicolumn{2}{|l|}{ Amino acids } \\
\hline Glycine & - \\
\hline L-Serine & - \\
\hline L-Cysteine & - \\
\hline L-Methionine & - \\
\hline L-Valine & - \\
\hline L-Leucine & - \\
\hline L-Isoleucine & - \\
\hline L-Alanine & + \\
\hline L-Glutamate & + \\
\hline L-Glutamine & + \\
\hline L-Aspartate & + \\
\hline L-A sparagine & + \\
\hline L-Ly sine & - \\
\hline L-Arginine & - \\
\hline L-Proline & + \\
\hline L-Histidine & - \\
\hline L,-Tyrosine & - \\
\hline
\end{tabular}

$a+$, Positive growth response $=$ a turbidity of 0.03 or more; - , negative growth response $=$ a turbidity of $<0.03$.

strain, which seems to be related to its natural habitat and to its seasonal variation in numbers in that habitat. No other strains of Aquaspirillum have been reported to have such a high optimal temperature, although Terasaki (6) reported temperature optima up to $37 \mathrm{C}$ for some strains. The Bengal strain is also unusual among Aquaspirillum strains in its ability to form pigments from aromatic amino acids: Hylemon et al. (2) reported that out of the 13 species of Aquaspirillum, only two could produce such pigments ( $A$. itersonii and $A$. peregrinum). Other differences between the Bengal strain and $A$. putridiconchylium include the ability of the former to grow on Seller agar, inability to grow on eosin-methylene blue agar, much stronger catalase activity, lack of ribonuclease activity, inability to use histidine as a sole carbon source, ability to use leucine, isoleucine, serine, lysine, and arginine as sole nitrogen sources, and inability to use cysteine, aspartate, and histidine as sole nitrogen sources. Furthermore, no serological cross-reaction occurred between the Bengal strain and $A$. putridiconchylium at anti-therolabile-antigen serum dilutions of 1:20. McElroy and Krieg (3) considered that only heterologous titers of $1: 160$ or higher justified a serological grouping of spirilla. Because of the various differences between the Bengal strain and $A$. putridiconchylium, we believe that the Bengal strain represents a new species, Aquaspirillum bengal. A formal description of this species follows, but it should be noted that the description is based on a single isolate and that the limits of variation within the species remain to be defined as additional strains are isolated.

Aquaspirillum bengal sp.nov. (ben.gal'. M.L. noun bengal Bengal.)

TABLE 5. Sole nitrogen sources for the Bengal aquaspirillum with succinate plus malate as the carbon source

\begin{tabular}{lc}
\hline \multicolumn{1}{c}{ Compound } & Growth response ${ }^{a}$ \\
\hline Ammonium sulfate & + \\
Potassium nitrate & - \\
Urea & + \\
Glycine & + \\
L-Alanine & + \\
L-Serine & - \\
L-Cysteine & + \\
L-Methionine & + \\
L-Valine & + \\
L-Leucine & + \\
L-Isoleucine & + \\
L-Threonine & + \\
L-Glutamate & + \\
L-Glutamine & - \\
L-Aspartate & + \\
L-Asparagine & + \\
L-Lysine & + \\
L-Arginine & + \\
L-Proline & - \\
L-Histidine & - \\
L-Tyrosine & - \\
L-Tryptophan & \\
\hline
\end{tabular}

$a+$, Positive growth response $=$ a turbidity of 0.03 or more; --, negative growth response $=$ a turbidity of $<0.03$ 
Description of species. Rigid helical cells, 0.9 to $1.2 \mu \mathrm{m}$ in diameter. Gram-negative. Motile by means of fascicles of flagella. Intracytoplasmic granules containing poly- $\beta$-hydroxybutyrate are present. Coccoid bodies are not predominant in older cultures. Temperature for optimal growth: $41 \mathrm{C}$. No growth at 10 or 45 C. Chemo-organotrophic, having a strictly respiratory metabolism with oxygen as the terminal electron acceptor. Cannot grow anaerobically with nitrate. Catalase, phosphatase, oxidase: positive. Indole: negative. Cannot hydrolyze casein, starch, hippurate, esculin, or urea. Gelatin not liquefied in 4 days. Light brown, water-soluble pigments formed from tyrosine or tryptophan. Acid reactions not produced from sugars. $\mathrm{H}_{2} \mathrm{~S}$ produced from cysteine. Can grow in the presence of $1 \%$ bile but not $1 \%$ glycine. Cannot grow in the presence of $1 \% \mathrm{NaCl}$. Water-soluble fluorescent pigment not produced. Can grow on triple sugar iron agar and Seller agar but not on EMB or MacConkey agar. Nitrate not reduced. A wide range of tricarboxylic acid cycle intermediates and a narrow range of amino acids can serve as sole carbon sources when ammonium ions are supplied as a nitrogen source; histidine cannot be utilized, however. A wide variety of amino acids, including serine, leucine, isoleucine, lysine, and arginine, can be utilized as sole nitrogen sources when succinate plus malate is supplied as the carbon source; cysteine, histidine, and aspartate cannot be utilized, however. The $\mathrm{G}+\mathrm{C}$ content of the DNA is $51 \mathrm{~mol} \%$. Source: Freshwater pond in West Bengal, India.

Type strain. The only isolate of the species presently available has been deposited with the American Type Culture Collection under the number 27641. We designate this strain as the type strain for the species. The description of the type strain is the same as that given above for the species.

\section{ACKNOWLEDGMENTS}

We are grateful to John L. Johnson of the Virginia Polytechnic Institute and State University Anaerobe
Laboratory, Blacksburg, for his help in determining the DNA base composition.

\section{REPRINT REQUESTS}

Address reprint requests to: Dr. Noel R. Krieg, Department of Biology, Virginia Polytechnic Institute and State University, Blacksburg, Va. 24061.

\section{LITERATURE CITED}

1. Canale-Parola, E., S. L. Rosenthal, and D. G. Kupfer. 1966. Morphological and physiological characteristics of Spirillum gracile sp. n. Antonie van Leeuwenhoek J. Microbiol. Serol. 32:113124.

2. Hylemon, P. B., J. S. Wells, Jr., N. R. Krieg, and H. W. Jannasch. 1973. The genus Spirillum: a taxonomic study. Int. J. Syst. Bacteriol. 23:340-380.

3. McElroy, L. J., and N. R. Krieg. 1972. A serological method for identification of Spirilla. Can. J. Microbiol. 18:57-64.

4. Neisser, M. 1903. Die Untersuchung auf Diphtheriebacillen in centralisierten Untersuchungsstationen. Hyg. Rundsch. 13:705-717.

5. Rittenberg, B. T., and S. C. Rittenberg. 1962. The growth of Spirillum volutans Ehrenberg in mixed and pure cultures. Arch. Mikrobiol. 42:138-153.

6. Terasaki, Y. 1972. Studies on the genus Spirillum Ehrenberg. I. Morphological, physiological and biochemical characteristics of water spirilla. Bull. Suzugamine Women's Coll. Nat. Sci., 16:1-146.

7. Terasaki, Y. 1973. Studies on the genus Spirillum Ehrenberg. II. Comments on type and reference strains of Spirillum and description of new species and new subspecies. Bull. Suzugamine Women's Coll. Nat. Sci. 17:1-71.

8. Umbreit, W. W., R. H. Burris, and J. F. Stauffer. 1972. Manometric techniques, p. 291-294, 5 th ed. Burgess Publishing Co., Minneapolis.

9. Wells; J. S., Jr., and N, R. Krieg. 1965. Cultivation of Spirillum volutans in a bacteria-free environment. J. Bacteriol. 90:817-818.

10. Williams, M. A., and S. C. Rittenberg. 1957. A taxonomic study of the genus Spirillum Ehrenberg. Int. Bull. Bacteriol. Nomencl. Taxon. $7: 49-111$ 